\author{
بررسى آزمايشگاهى اثر شكاف در بدنه آبشكن بر كنترل آبشستخى اطراف \\ آن در قوس •11 آدرجه \\ بيتا جعفرى و عليرضا مسجدى "

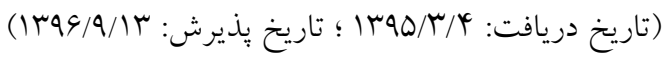

جكيده

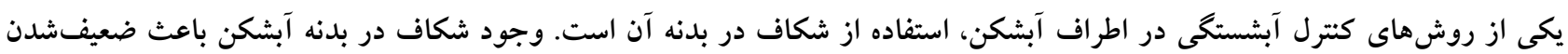

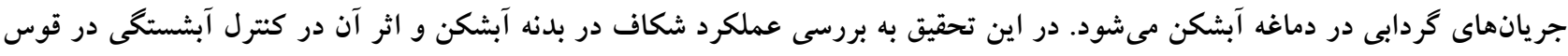

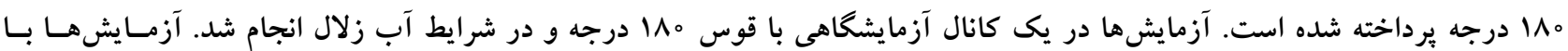

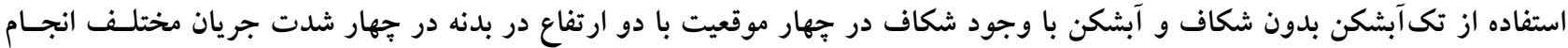

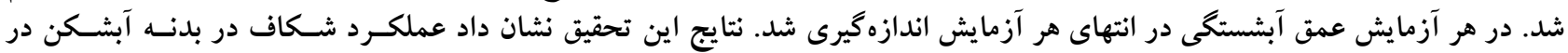

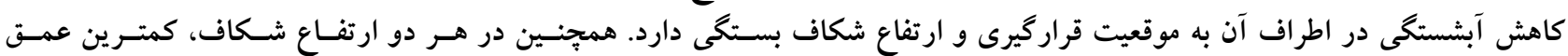

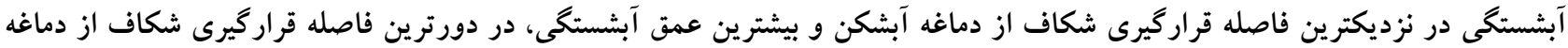
آبشكن اتفاق افتاد.

وازمهاى كليدى: آبشكن، شكاف، عمق آبشستخى، قوس •1 ا درجه 
مواد بسـتر از اطـراف آبشـكن و در دراز مــدت باعـث ايجـاد

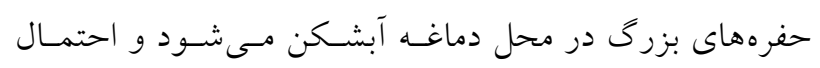

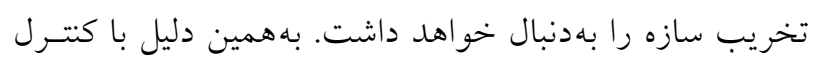

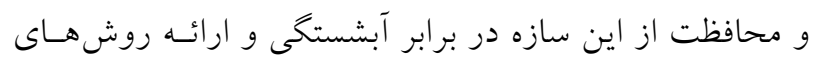

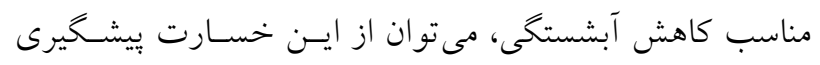

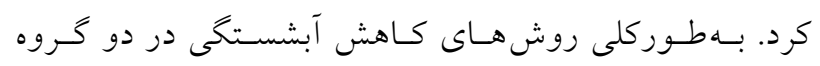
روشهاى مقاوم سازى بستر و روش هاى تغيير الكوى جريان

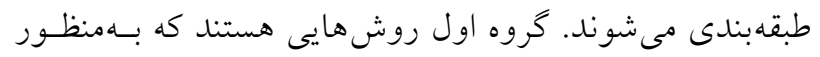

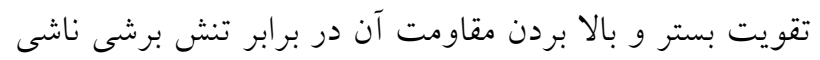

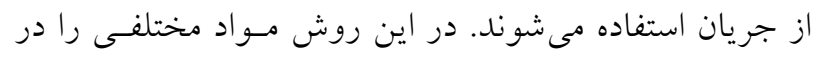

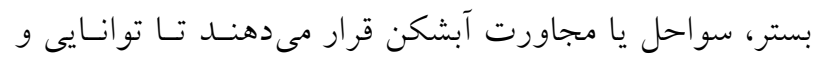

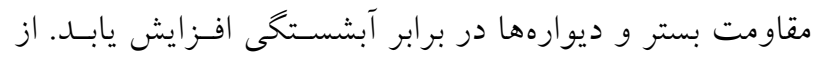

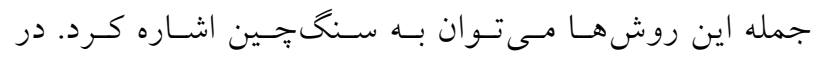

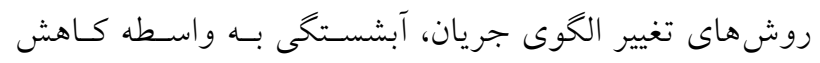

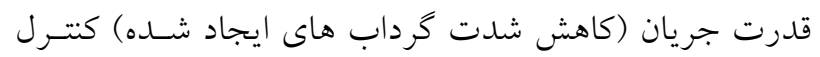

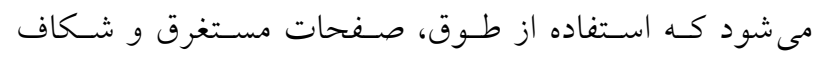

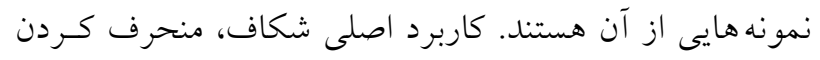

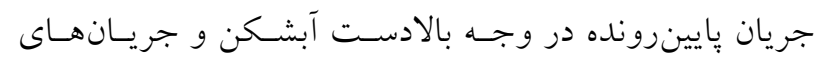
كنارى در اطراف آن است. تعبيه شكاف موجب كاهش ميـز بـان بان

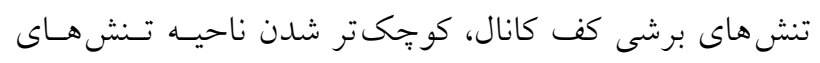

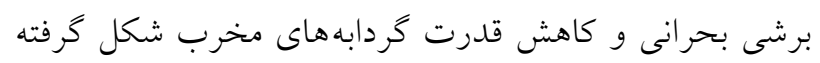

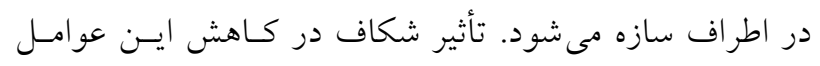

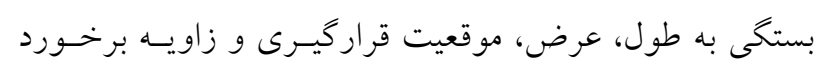
جريان با امتداد شكاف دارد. محققسين مختلفـى از جملـه بيرمحمـــى (Y)، ايـزدىنيـا و

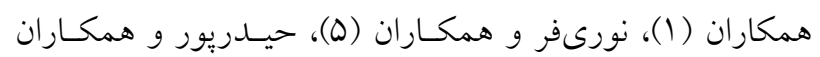

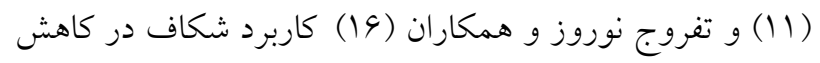

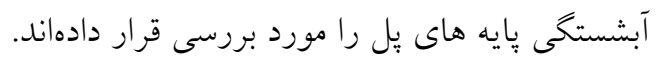

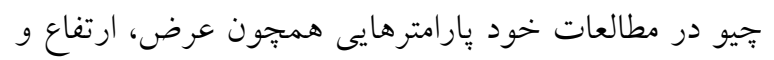

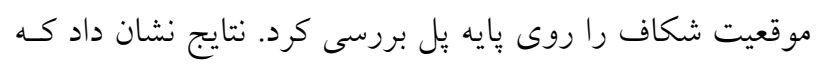

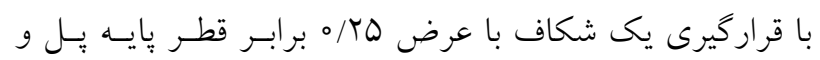

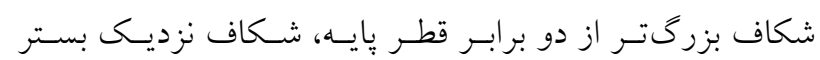

آبشكن ها سازههايى هسـتند كـهـ بـر اى سـاماندهى رودخانـه در

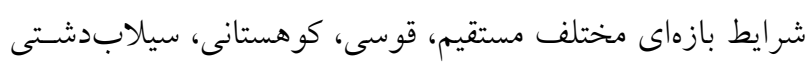

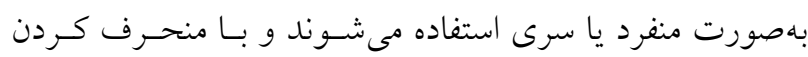

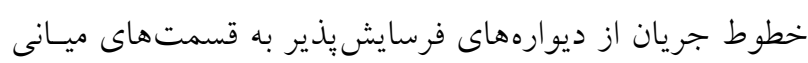

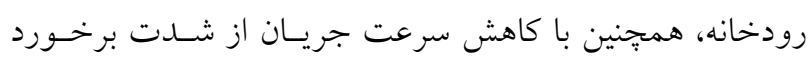

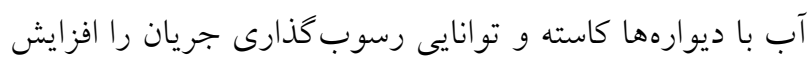

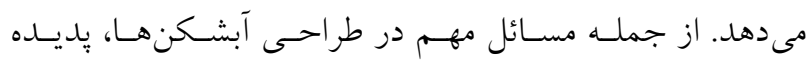

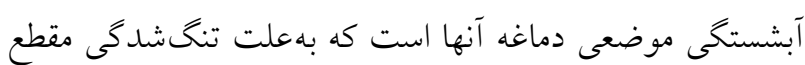

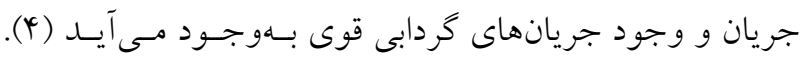

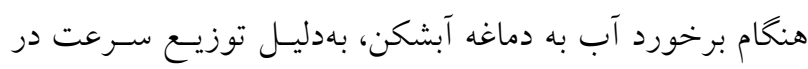

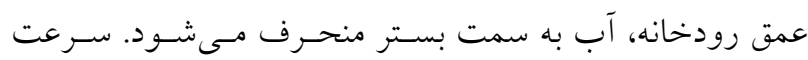

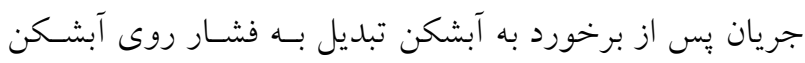
مىشود و بدين ترتيب كراديان فشار ايجـاد شــه باعـث ايجـاد جريانى به طرف كف بستر مى شود. سرعت اين جريان بـهدليسل

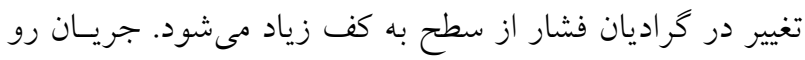

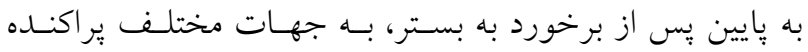

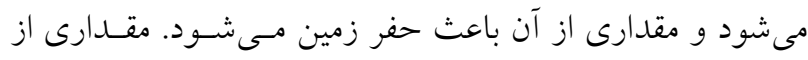

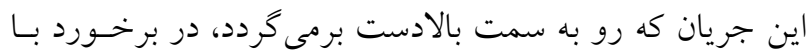

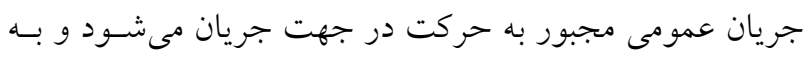

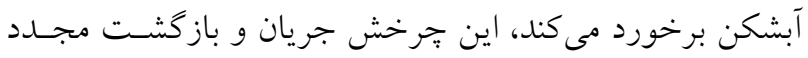

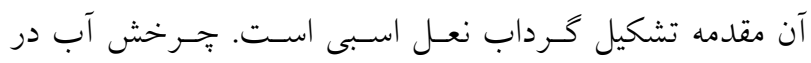

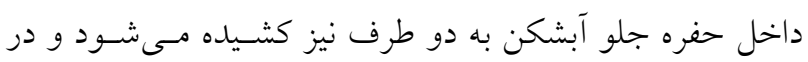

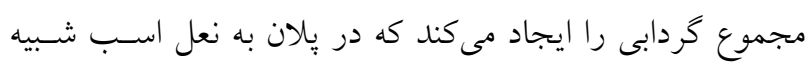

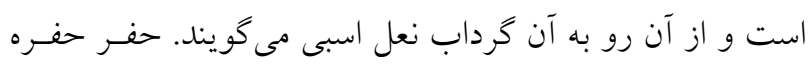

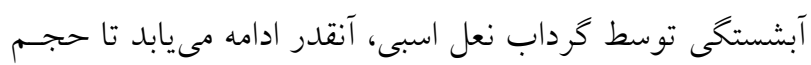

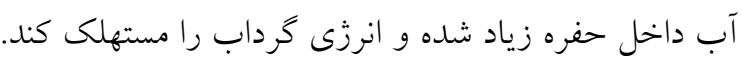

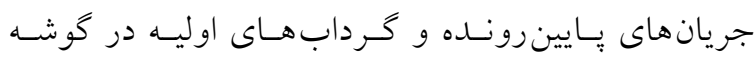

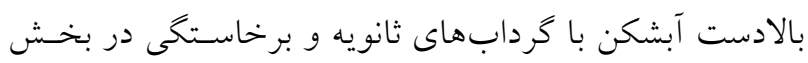

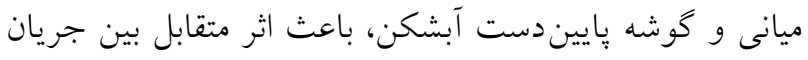

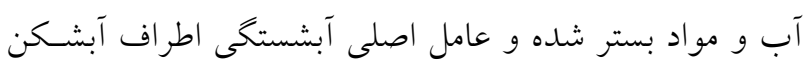

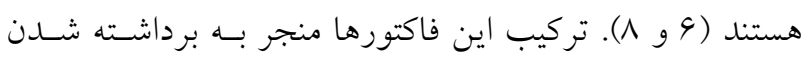




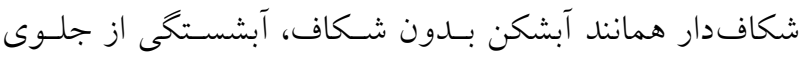

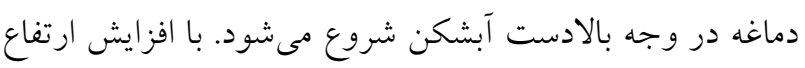

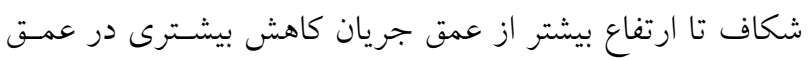

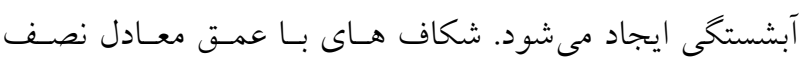

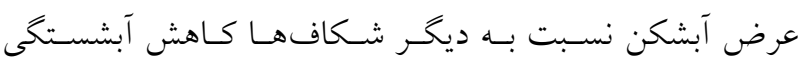

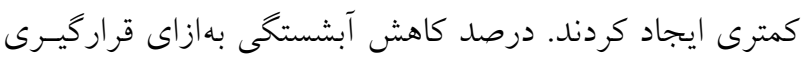

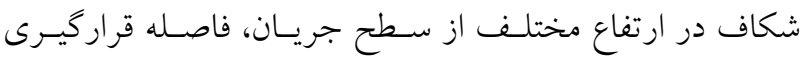
مختلف از دماغه و عمق شكاف مختلف بين /1/1 تا مY درصد بهدست آمد. درصورتى كه اين عمـق بـهدرسـتى بــرآورد نشـوده،

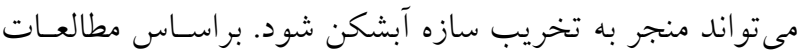

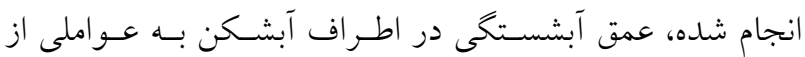
جمله ارتفاع شكاف، عرض شكاف، موقعيت قراركيرى شكاف بر روى آبشكن بستى دارد (r).

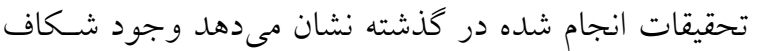

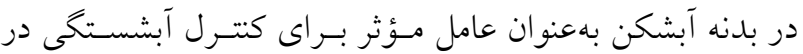
اطراف آبشكن است. با توجه به اينكه الكوى جريان و تغييـرات

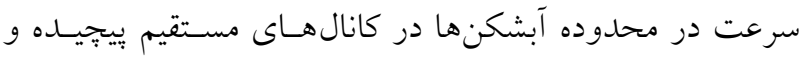

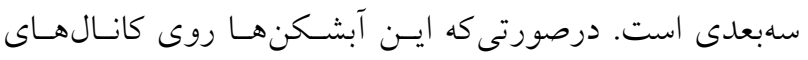

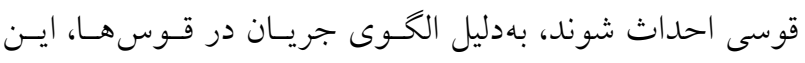

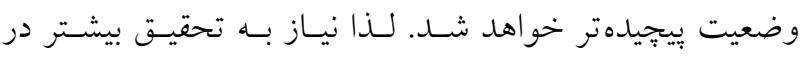
خصوص تأثير ارتفاع و موقعيت قرارگيسرى شـكاف در بدنـه و

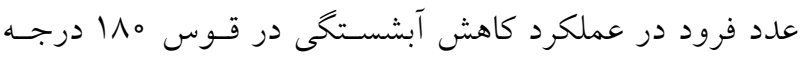

\section{مواد و روشها}

با در نظر گرفتن جريان دائمى و ثابت بودن خصوصسيات سـيال

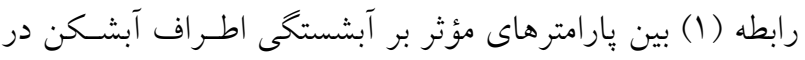
حالت تعادل برقرار است: $\mathrm{f}\left(\mathrm{B}, \mathrm{R}, \theta, \mathrm{d} \Delta \circ, \mathrm{S}_{\mathrm{o}}, \mathrm{L}_{\mathrm{a}}, \mathrm{B}_{\mathrm{a}}, \mathrm{W}, \mathrm{Y}, \mathrm{T}, \mathrm{X}, \mathrm{y}_{\mathrm{o}}, \mathrm{V}, \mathrm{g}, \rho_{\mathrm{w}}, \mu, \rho_{\mathrm{s}}, \mathrm{ds}\right)=。$ در رابطه (1)، B عرض مجرا، R شعاع مركزى قـوس، $\theta$ زاويـه

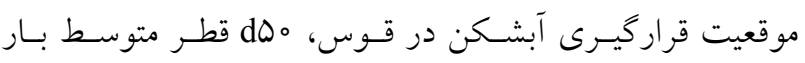

بهميزان م r درصد و نزديك سطح آب تا ينج درصد بـه كـاهش

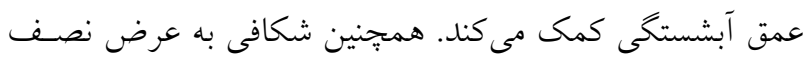

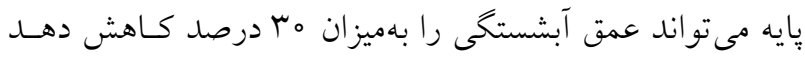

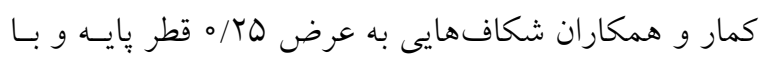

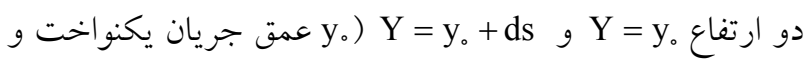

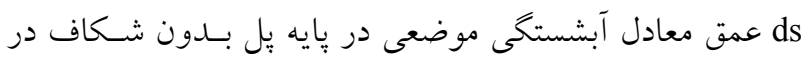
يايههاى استو انهاى ايجاد كردند. ايشان به اين نتيجه رسيدند كـهـ

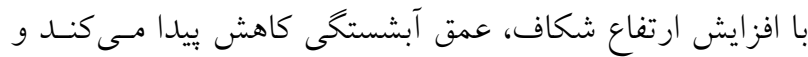

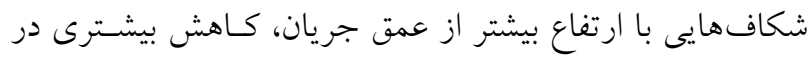
عمق آبشستكى ايجاد مى كند (I). مونكادا و همكاران به بررسى عملكــد طـوق و شـكاف در

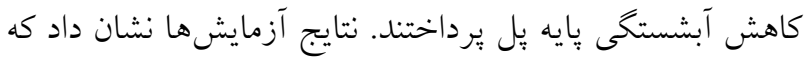

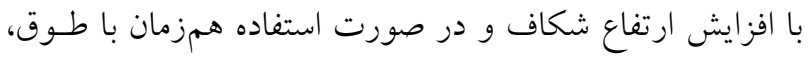

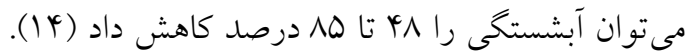

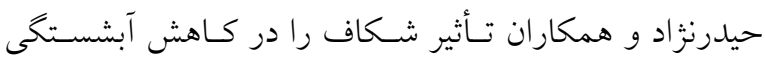

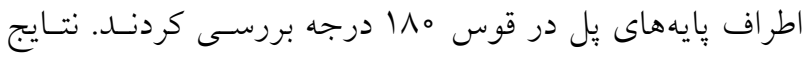

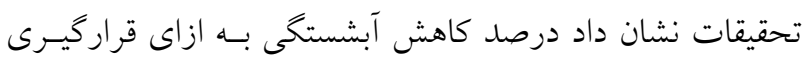

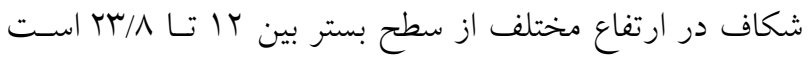

مسجدى و مرادى بر روى آبشتيكى در اطراف آبشكن در

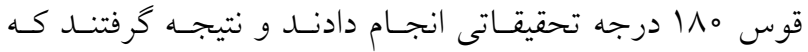

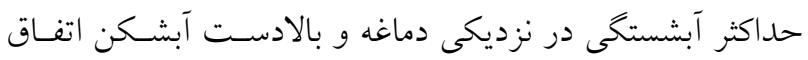

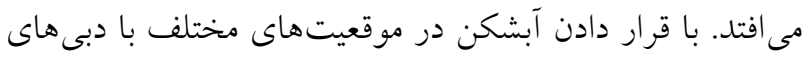

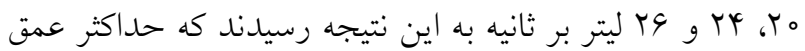
آبشستخى در نيمه اول قوس (صفر تا ه9 درجه ) كمتــر از نيمـهـ

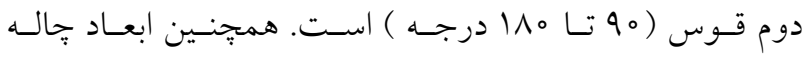

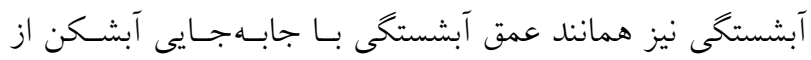

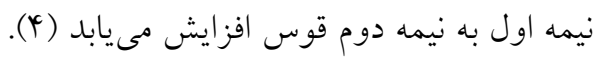

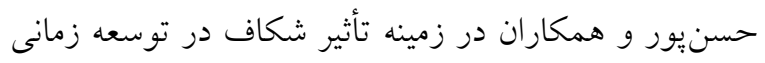
آبشستخى اطر اف آبشكنها در مسـير مستقيم تحقيقـاتى انجـام

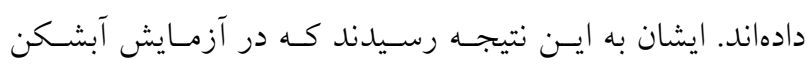




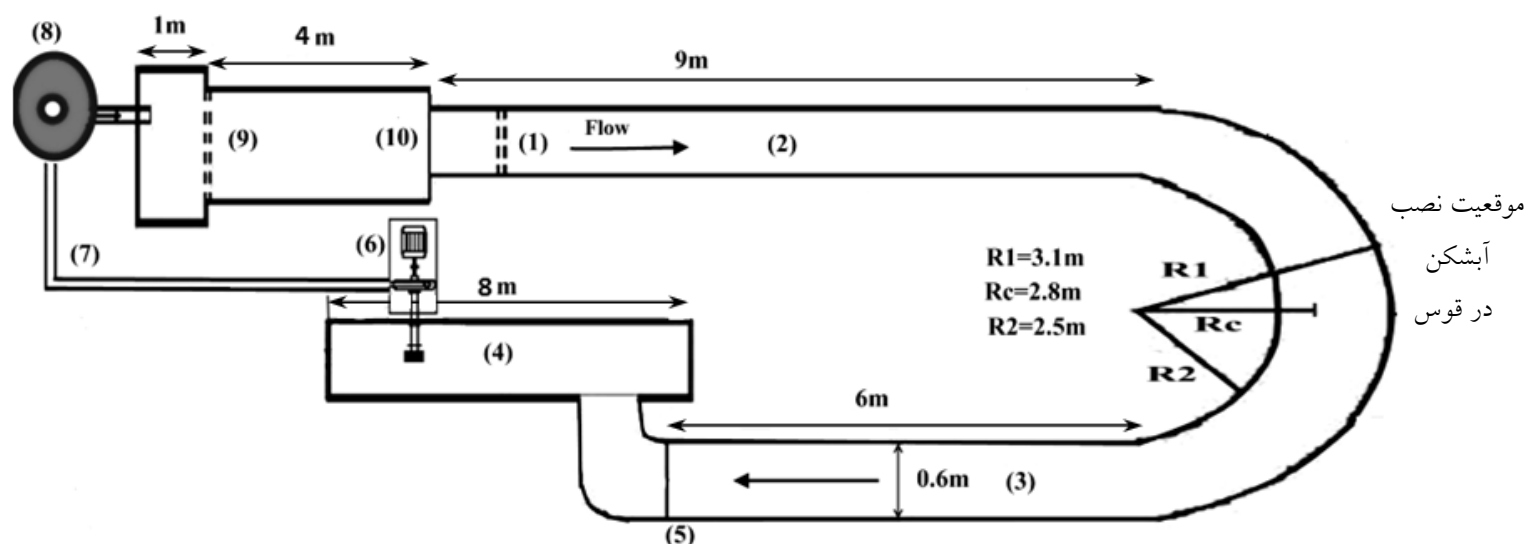

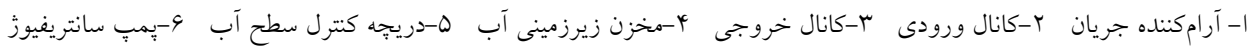

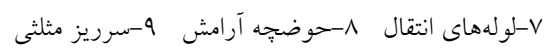

شكل 1. فلوم آزمايشعاهى

مركزى R=r/A m و عرض R=r/9 m انجام شد. انحناى نسبى قوس R/B=Y/N بود كه قوس را در رده قوسهــاى ملايسم قـرار

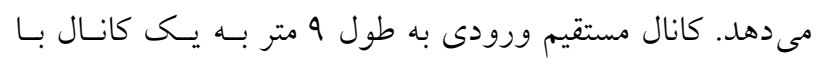

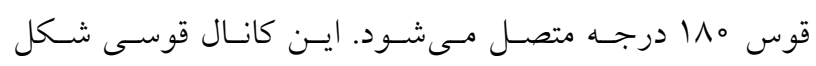

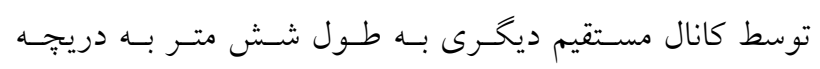

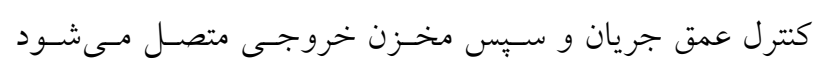

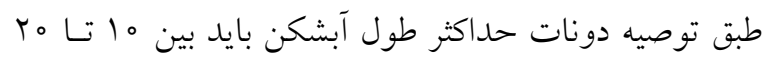

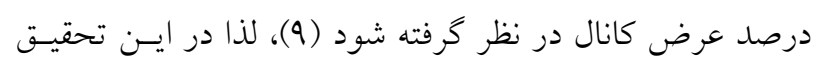

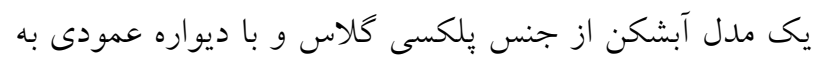

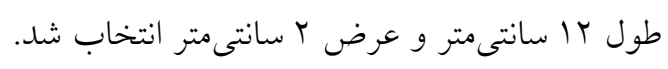

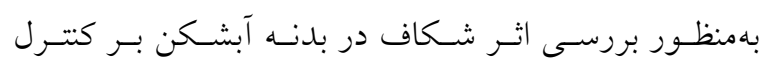

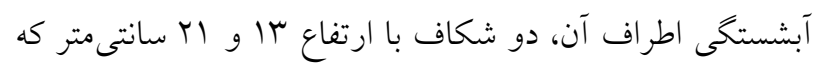

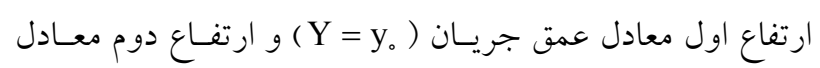
عمق جريان و عمق تعـادل آبشستخىى (

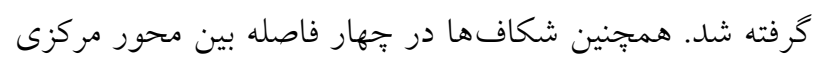

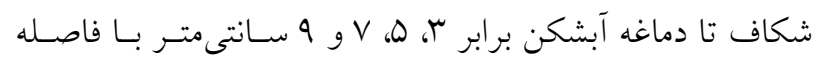

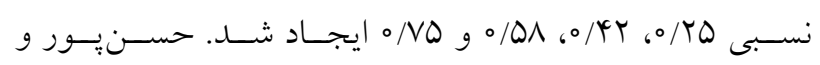

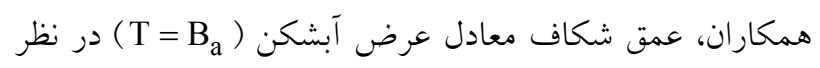

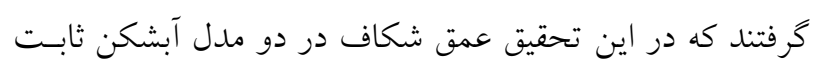

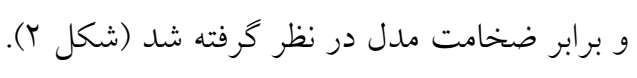

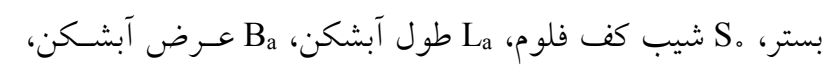

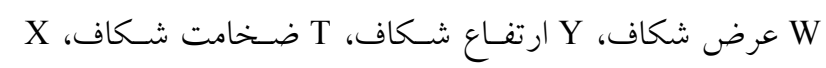

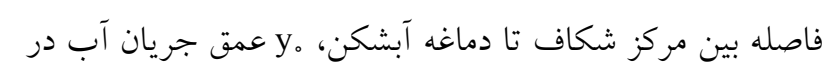

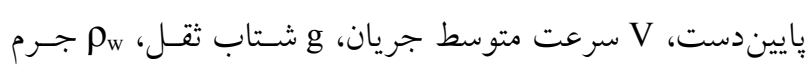

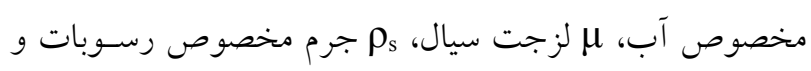

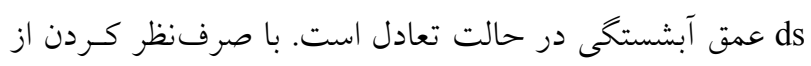

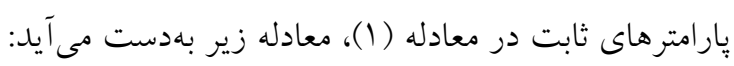
$\mathrm{f}\left(\mathrm{L}_{\mathrm{a}}, \mathrm{Y}, \mathrm{X}, \mathrm{y}_{\mathrm{o}}, \mathrm{V}, \mathrm{g}, \rho_{\mathrm{w}}, \mathrm{ds}\right)=$ 。

با استفاده از تئورى باكينخهام رابطه (Y) بهصورت زير بلدون

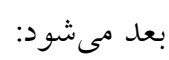

$\mathrm{f}\left(\mathrm{Fr}, \frac{\mathrm{X}}{\mathrm{L}_{\mathrm{a}}}, \frac{\mathrm{ds}}{\mathrm{y}_{\mathrm{o}}}\right)=。$

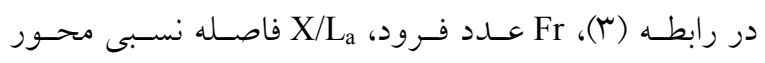

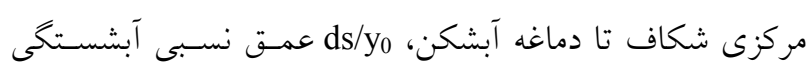

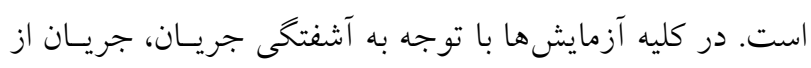
نوع متلاطم بود و عدد رينولدز حذف شد.

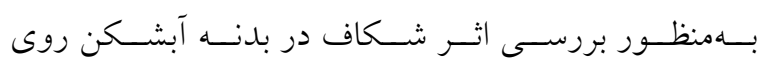

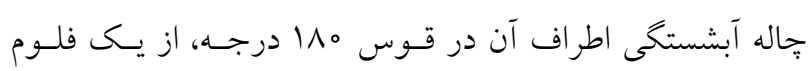

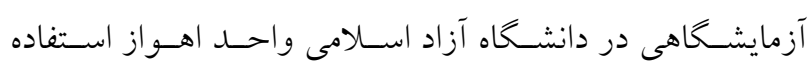

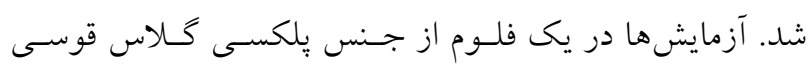

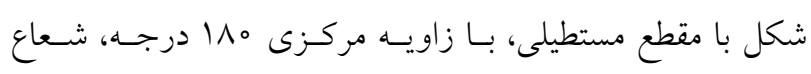



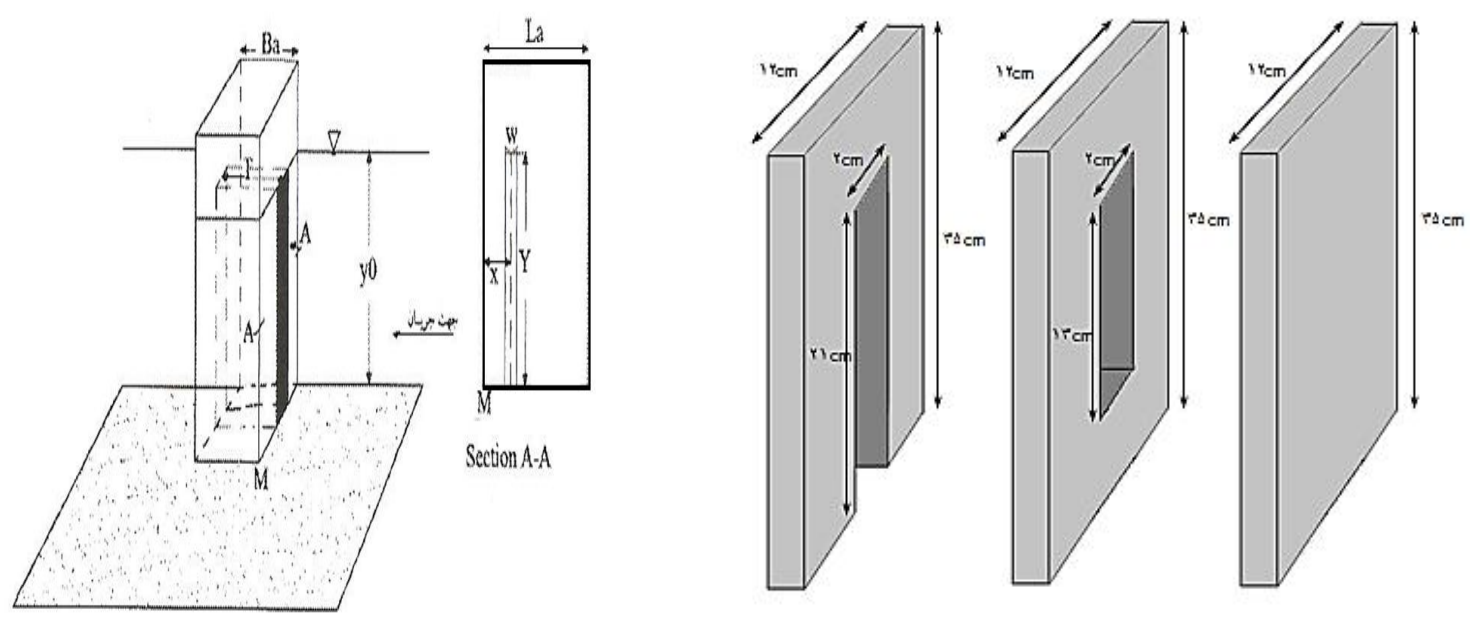

شكل r. آبشكن همر اه با شكاف در بدنه

از ارابه متحرك، بستر كانال تحـت شـيب ثابـت مسـطح حسدود

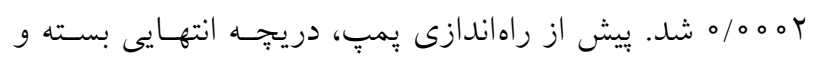

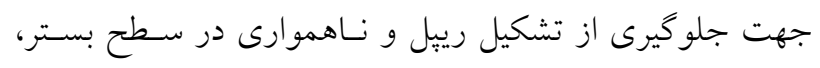

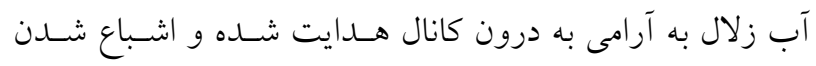

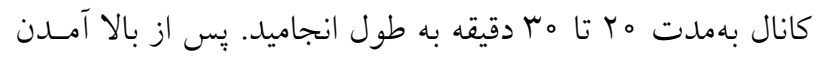

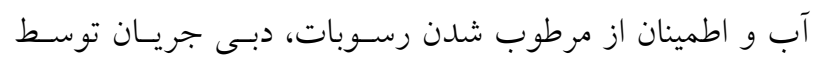

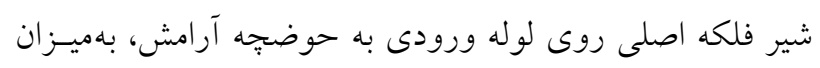

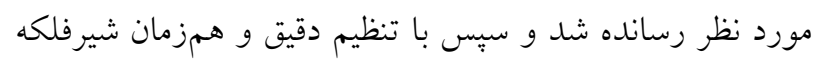

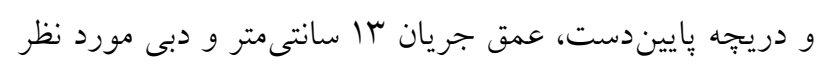

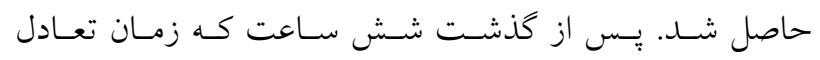
رسوبات در اطراف آبشكن محسوب مىشود، با خاموش كـردن

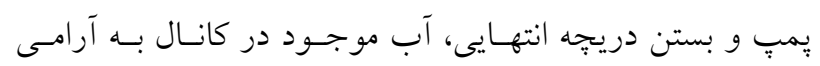
زهكشى شد تا تأثيرى بر روى تويـو گرافى بسـتر ايجـاد نشـود.

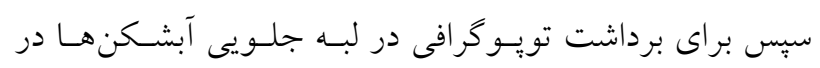

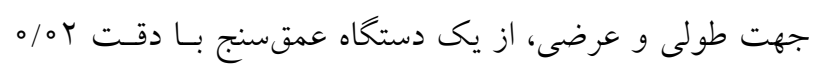

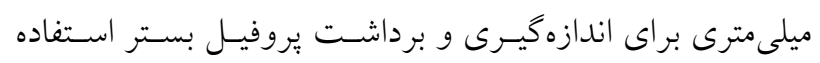

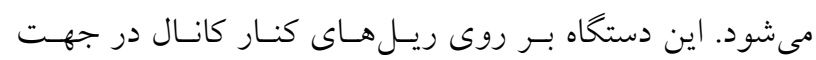

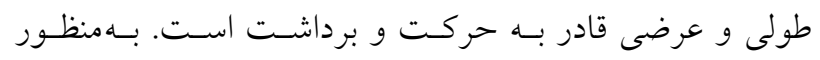

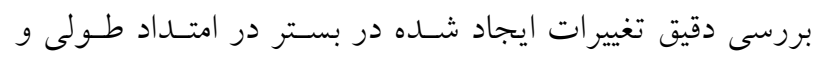
عرضى فاصله نقاط برداشت ه/ ا سانتىمتر در نظر كرفته شد.
طبق توصيه ملويل و جيو بهمنظور كاهش اثر عمـق جريـان

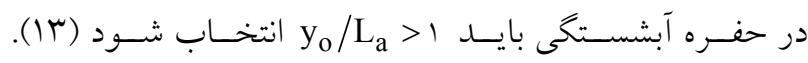

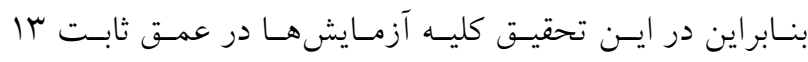

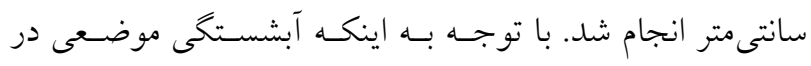

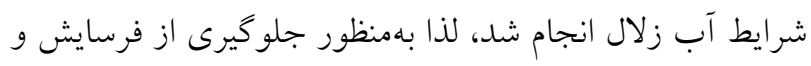

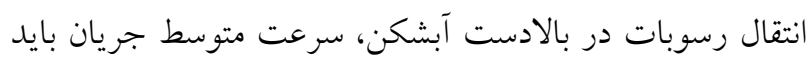

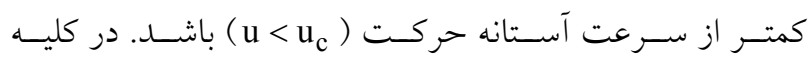

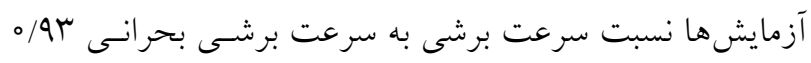

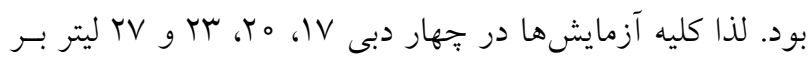
ثانيه انجام شد و دبى مورد نياز توسط سرريز مثلثى هو 9 درجسه در ابتداى ورودى فلوم اندازهگيرى شد.

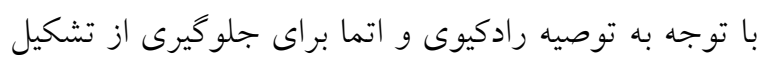

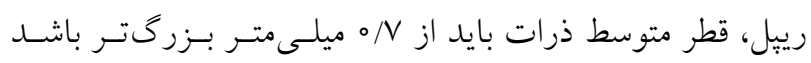

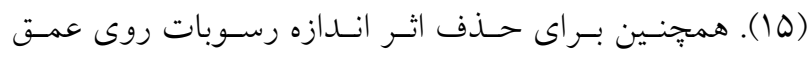

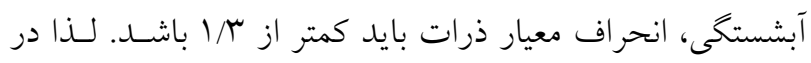

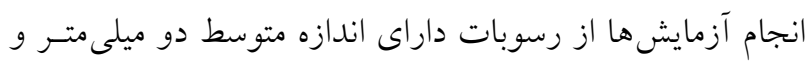
انحراف معيار ب/ ا استفاده شد.

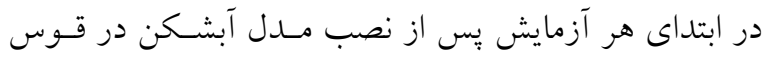

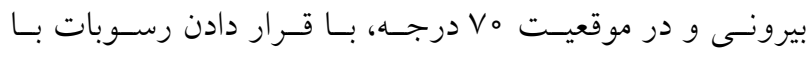

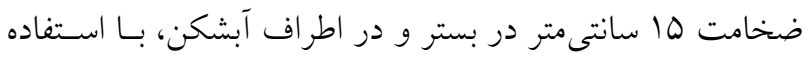




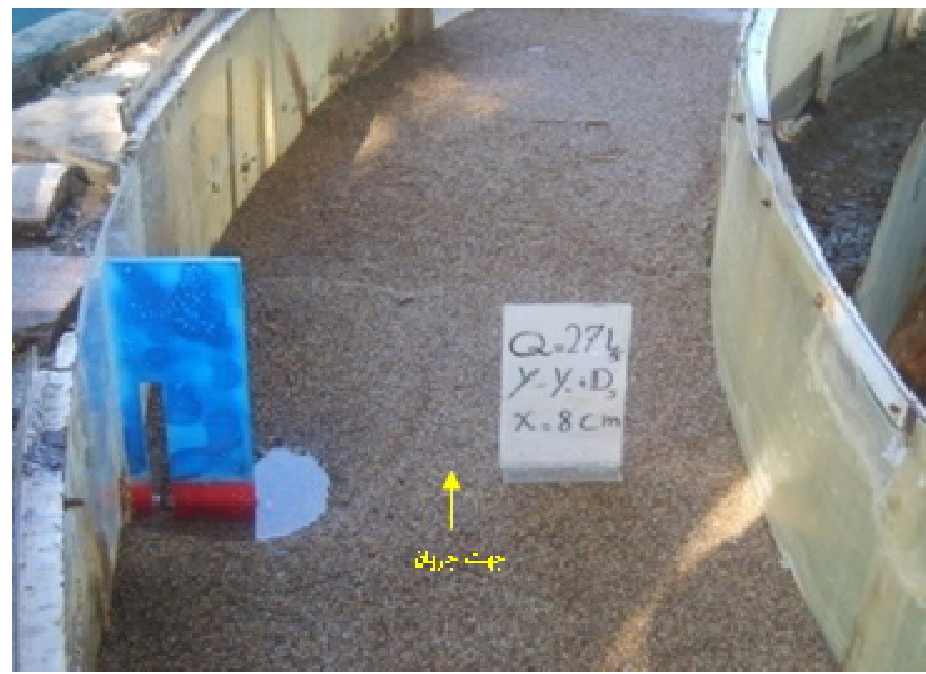

شكل r. آبشكن شكافدار و آبشتيكى در اطراف آن بعد از آزمايش

اطراف آن مسىشـود، همجنـين در دو ارتفـاع شـكاف، حــاقل

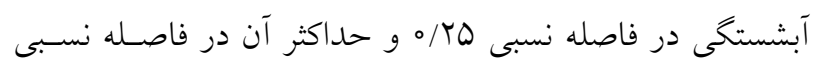

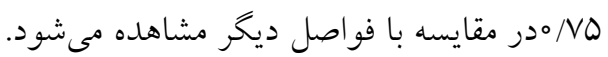

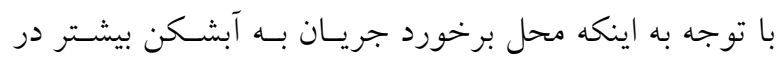

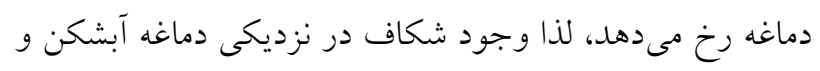

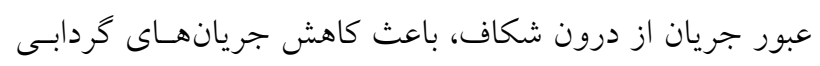

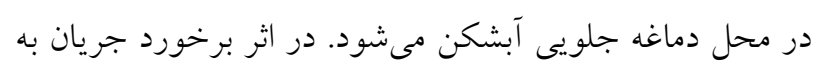

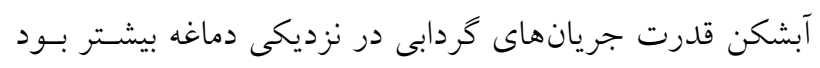

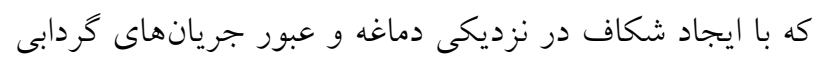

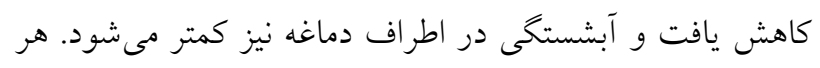

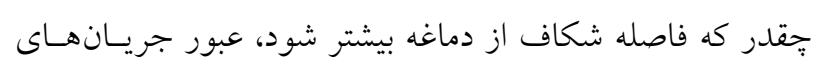

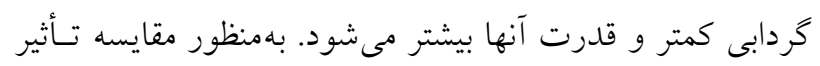

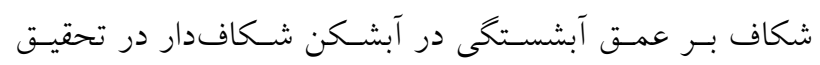

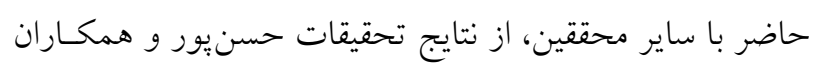

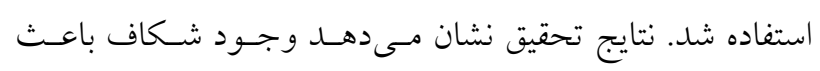

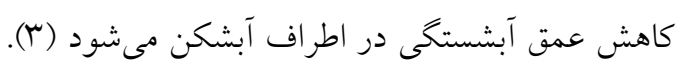

بررسى اثر شدت جريان بر عمق آبشستخى در اطراف آبشكن شكافدار شكل هاى (q) و (V) بروفيل هاى طولى و عرضسى بــدون بعـد و

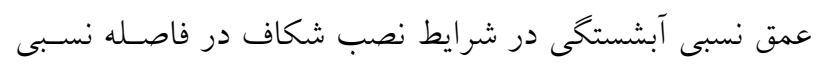

\section{نتايج و بحث}

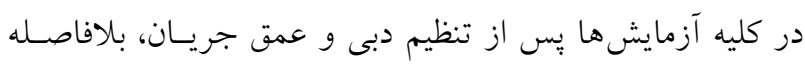

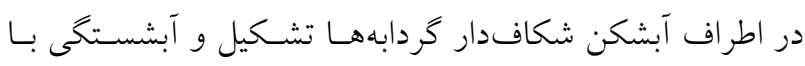

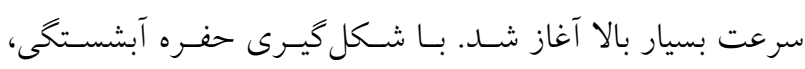
رسوب هاى برخاسته از حفره به سمت باييندست منتقل شدند.

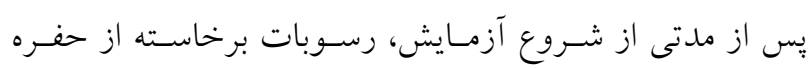

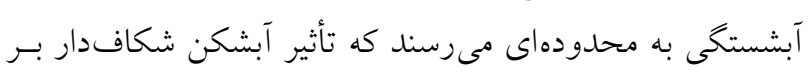

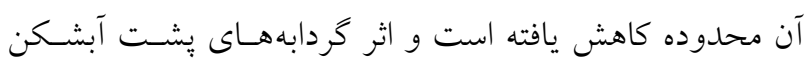

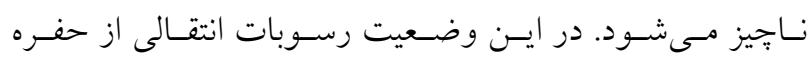

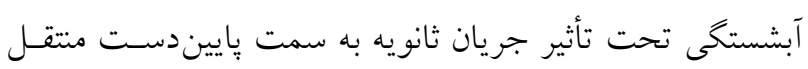

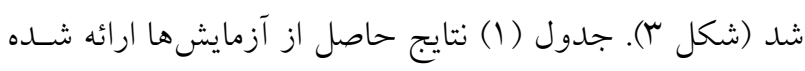

بررسى اثر فاصله نسبى شكاف از دماغه آبشكن بر آبشستكى

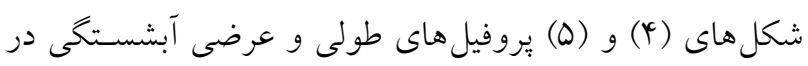

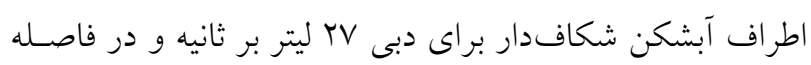

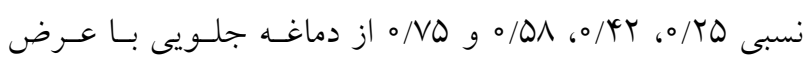

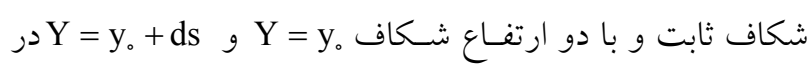
دو حالت با شكاف و بــدون شكاف ارائسه شــده اسـت. نتـايج

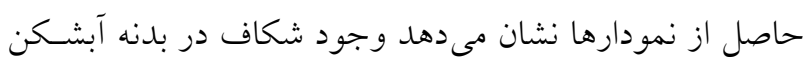

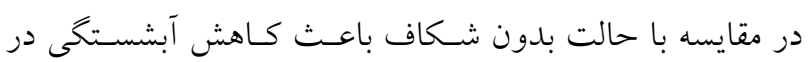


جدول ا. نتايج حاصل از آزمايشها در دبى و فاصله نسبى شكاف مختلف

\begin{tabular}{|c|c|c|c|c|c|c|}
\hline $\mathrm{ds}(\mathrm{cm})$ & $\mathrm{Fr}$ & $\mathrm{V}(\mathrm{m} / \mathrm{s})$ & $\mathrm{Q}\left(\mathrm{m}^{r} / \mathrm{s}\right)$ & $\mathrm{y}_{0}(\mathrm{~cm})$ & $\mathrm{X} / \mathrm{L}_{\mathrm{a}}$ & $X(\mathrm{~cm})$ \\
\hline$r / r$ & $0 / 19$ & $0 / T Y$ & $0 / 01 \mathrm{~V}$ & \multirow{4}{*}{ r } & \multirow{4}{*}{ بدون شكاف } & \multirow{4}{*}{-} \\
\hline$\Psi / V$ & س & $0 / T G$ & $0 / 0 Y_{0}$ & & & \\
\hline $9 / 4^{4}$ & $0 / 49$ & $0 / \pi 9$ & מYוס & & & \\
\hline$\Lambda / \circ$ & $0 / N$ &.$\pi \Delta$ & \%०TV & & & \\
\hline $1 / 0$ &.$/ 19$ & O/YY & $0 / 01 \mathrm{~V}$ & \multirow{4}{*}{ ir } & \multirow{4}{*}{$\circ / T \Delta$} & \multirow{4}{*}{$r$} \\
\hline$T / V$ & س & $0 / K G$ & ०० భ० & & & \\
\hline$r / r$ & $0 / 49$ & $0 / 79$ & \% & & & \\
\hline$Q / \circ$ & $0 / N$ & 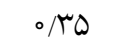 & ०/०TV & & & \\
\hline$T / 1$ & $0 / 19$ & O/TY & $0 / 01 \mathrm{~V}$ & \multirow{4}{*}{ rI } & \multirow{4}{*}{$\circ / T \Delta$} & \multirow{4}{*}{$r$} \\
\hline$r / 9$ & 低 & $0 / K 9$ & ०/०Y० & & & \\
\hline $4 / 9$ & $0 / 49$ & $0 / \pi q$ & ס & & & \\
\hline$\Delta / V$ & $0 / \mu 1$ & $\circ / \mu$ & $0 / 0 T V$ & & & \\
\hline $1 / r$ & $0 / 19$ & $0 / T Y$ & $0 / 01 \mathrm{~V}$ & \multirow{4}{*}{ Ir } & \multirow{4}{*}{ OMY } & \multirow{4}{*}{0} \\
\hline$r / r$ & س & $0 / T G$ & ०/०Y० & & & \\
\hline$r / \omega$ & $0 / 49$ & $0 / 49$ & سTH & & & \\
\hline$\Delta / \Delta$ & $0 / N 1$ & $\circ / \mu$ & \%०YV & & & \\
\hline$T / Q$ & $0 / 19$ & O/TY & $0 / 01 \mathrm{~V}$ & \multirow{4}{*}{ rI } & \multirow{4}{*}{ OMY } & \multirow{4}{*}{0} \\
\hline$r / \Lambda$ & 低 & $0 /$ KG & ०/०५० & & & \\
\hline$y / \Lambda$ & $0 / 49$ & $0 / 79$ & سYו & & & \\
\hline $9 / \pi$ & $\circ / \mu 1$ & $\circ \pi \Delta$ & ००TV & & & \\
\hline $1 / \pi$ & $0 / 19$ & O/TY & $0 / 01 \mathrm{~V}$ & \multirow{4}{*}{ Ir } & \multirow{4}{*}{$\circ / \Delta \Lambda$} & \multirow{4}{*}{ V } \\
\hline$r / \mu$ & 低 & $0 / T 9$ & ०/०Y० & & & \\
\hline$\varphi / 0$ & $0 / 49$ & $0 / 79$ & ס & & & \\
\hline$Q / \Lambda$ & $0 / N$ & $\circ \pi \Delta$ & $\circ / 0 T V$ & & & \\
\hline$T / V$ & $0 / 19$ & O/TY & $0 / 01 \mathrm{~V}$ & \multirow{4}{*}{ rI } & \multirow{4}{*}{$\circ / \Delta \wedge$} & \multirow{4}{*}{ V } \\
\hline$r / q$ & س & $0 / T G$ & ०/०Y० & & & \\
\hline$\Delta / \mu$ & $0 / 49$ & $0 / \pi 9$ & & & & \\
\hline $9 / \mathrm{V}$ & $0 / \mu 1$ & $\circ / \mu \Delta$ & ००TV & & & \\
\hline $1 / V$ & $0 / 19$ & O/TY & $0 / 01 \mathrm{~V}$ & \multirow{4}{*}{ Ir } & \multirow{4}{*}{$\circ / V \Delta$} & \multirow{4}{*}{9} \\
\hline$\Gamma / \Lambda$ & L/r & $0 / \pi q$ & ०/०५० & & & \\
\hline $4 / 9$ & $0 / 49$ & $0 / 49$ & ס & & & \\
\hline $9 / 1$ & $0 / N 1$ & $\circ / \pi \Delta$ & $0 / 0 T V$ & & & \\
\hline$T / q$ & $0 / 19$ & O/TY & $0 / 01 \mathrm{~V}$ & \multirow{4}{*}{ rI } & \multirow{4}{*}{$\circ / N Q$} & \multirow{4}{*}{9} \\
\hline$\varphi / \Delta$ & س & $0 / T G$ & $0 / 0 Y_{0}$ & & & \\
\hline$\Delta / \Delta$ & $0 / \pi 9$ & $0 / \pi q$ & & & & \\
\hline $\mathrm{V} / \mathrm{r}$ & $0 / \mu 1$ & ० & $\circ / 0 T V$ & & & \\
\hline
\end{tabular}




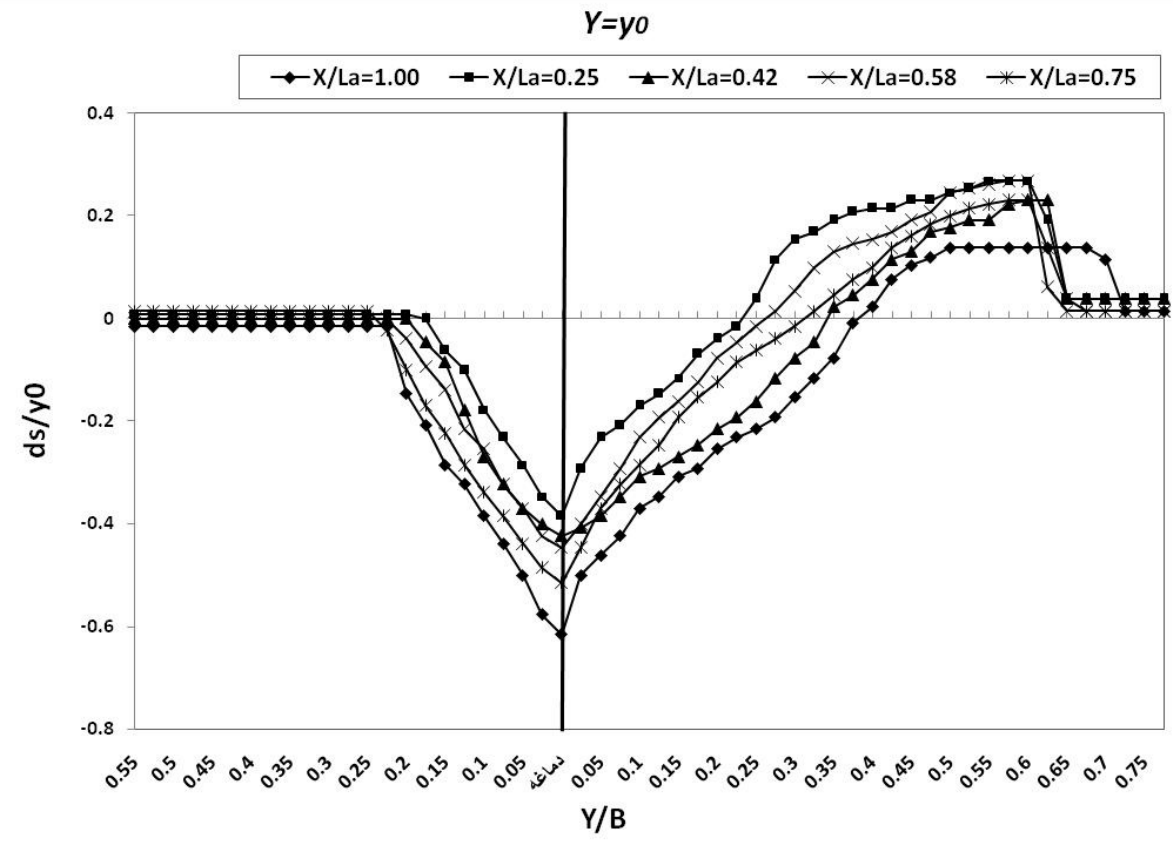

$Y=y 0+d s$

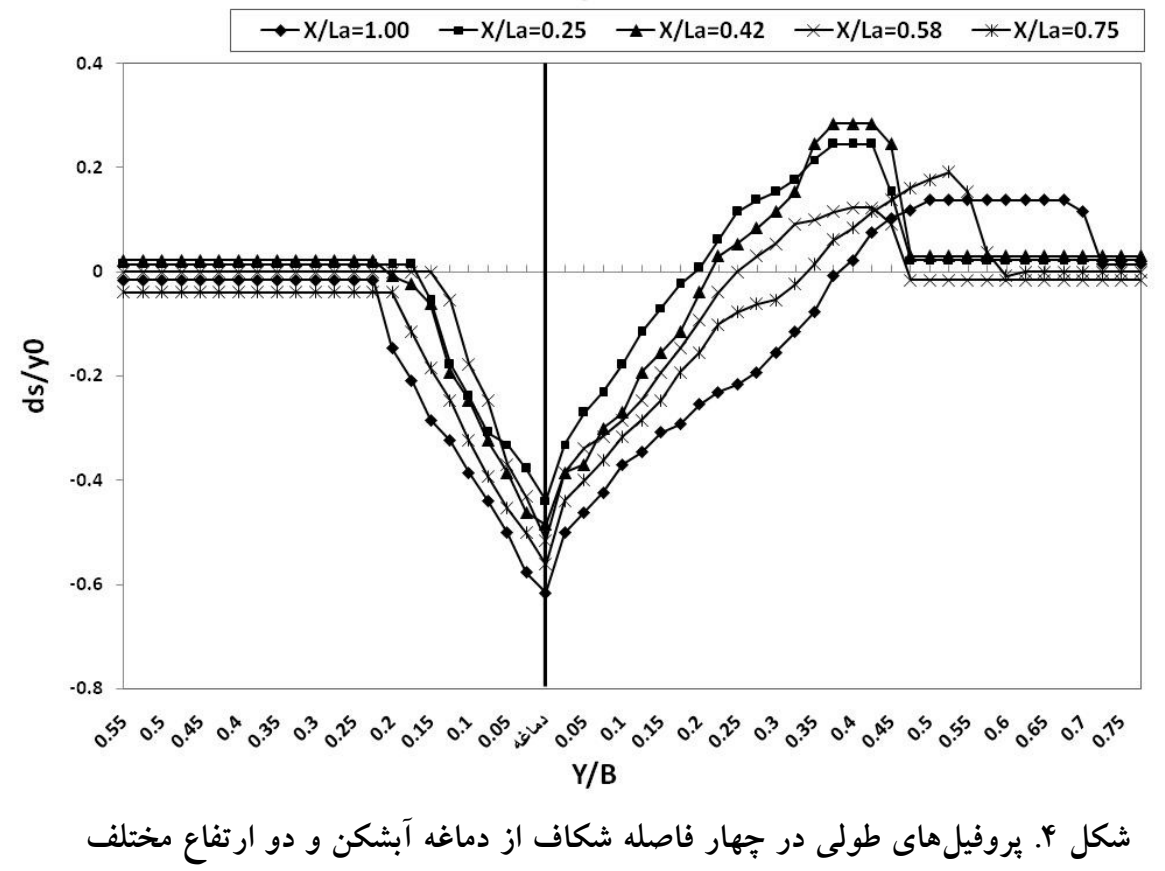

افزايش مىيابد. افزايش شدت جريان در كانال اصلى باعث

افزايش سرعت جريان در كانال اصلى شده و در نتيجه باعث افزايش جريانهاى كردابى در نزديكى دماغه جلويى آبشكن

مىشود، افزايش جريانهاى گردابى باعث افزايش توان حمل

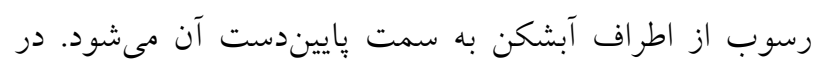

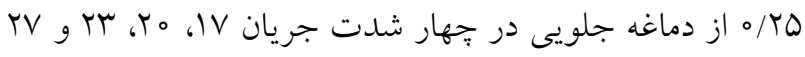
ليتر بر ثانيه و در دو ارتفاع شكاف نشان مىدهد. نتايج حاصل از نمودارها نشان مىدهد شدت جريان با عمق آبشستكى در اطر اف آبشكن نسبت مستقيم دارد و با افزايش شدت جريان در شرايط وجود شكاف در بدنه آبشكن، عمق آبشستكى نسبى 

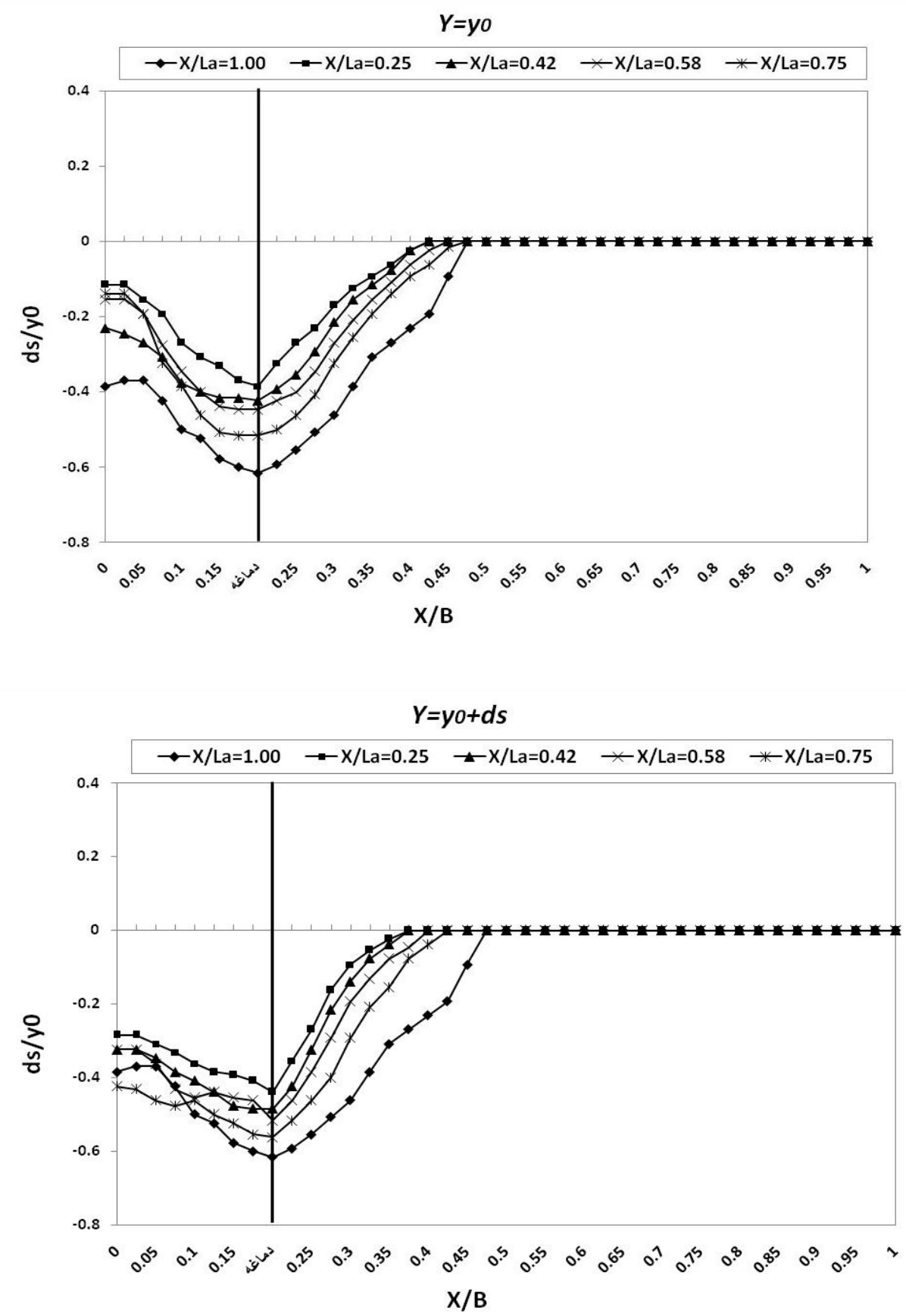

شكل ه. يروفيلهاى عرضى در جهار فاصله نسبى شكاف از دماغه آبشكن و دو ارتفاع مختلف

نتيجه افزايش شدت جريان باعث ايجاد جاله در اطراف آبشكن همانند عمق حداكثر آبشستكى با افزايش شدت جريان، افزايش

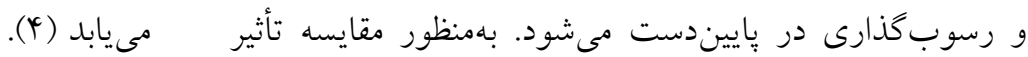

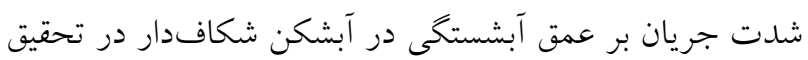

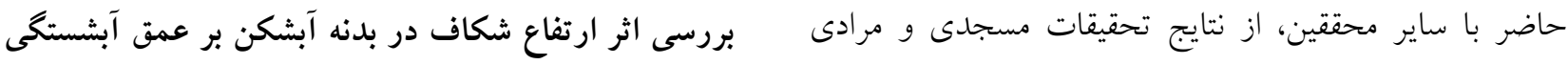

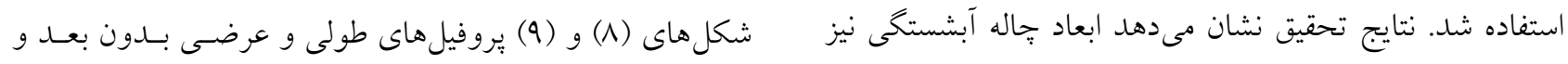




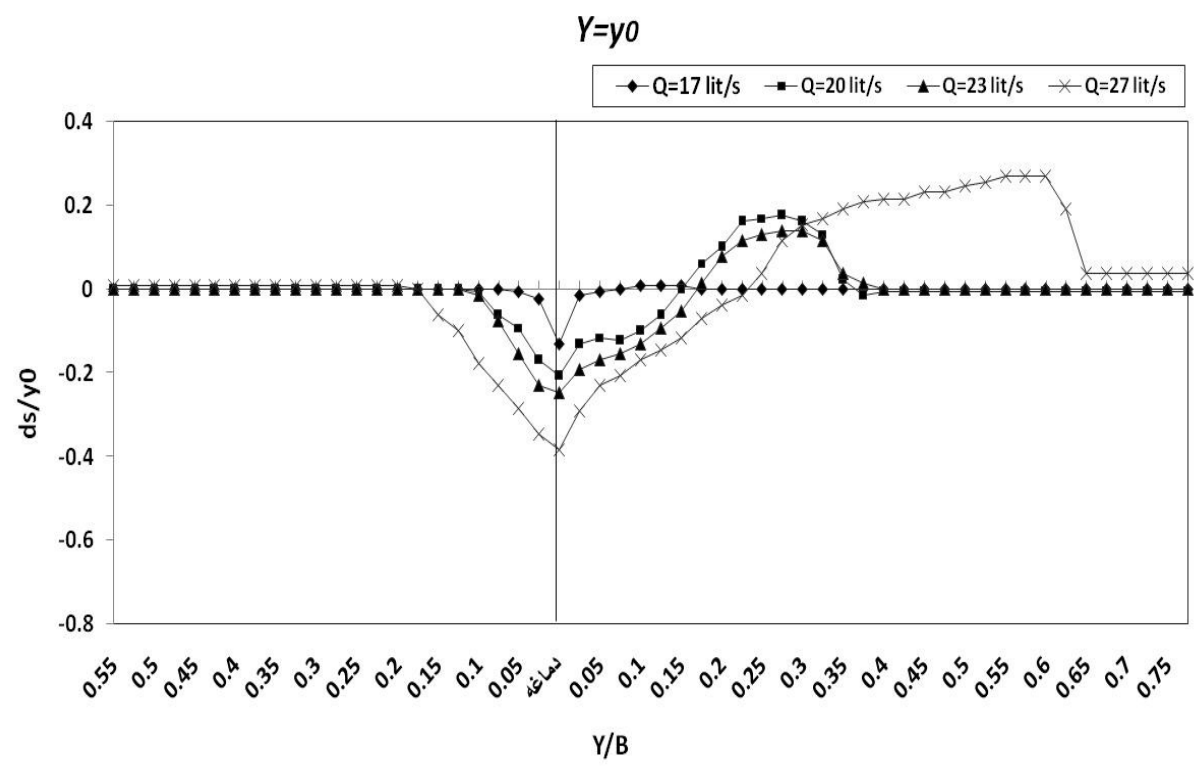

$Y=y 0+d s$

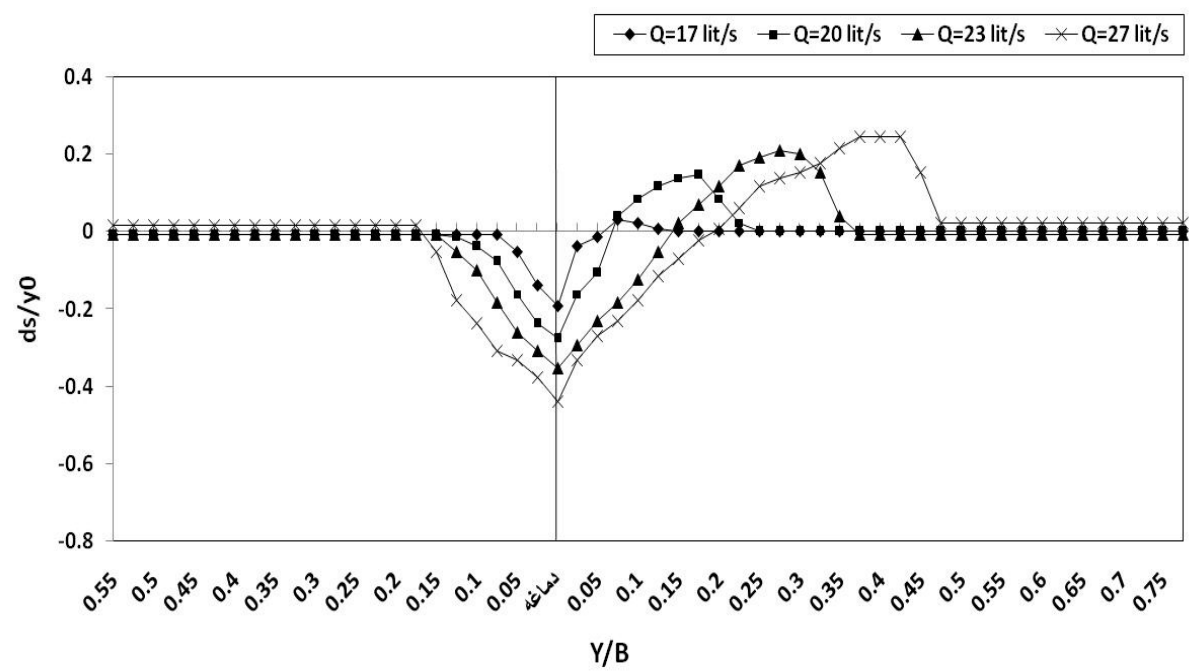

شكل צ. بروفيل طولى جاله آبشستخى در دبىهاى مختلف

كمتر از ارتفاع شكاف Y = =y。 +ds مشاهده مسىشـود. Y با ايجاد شكاف تا سطح رسوبات ( Y=y。 )، جريانهاى گردابى

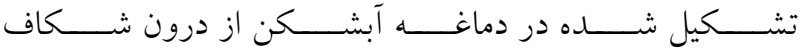
عبور كرده و به سمت باييندسـت حركت مسىكنــد و قـدرت جريانهاى گردابى در اطراف دماغه آبشـكن نسـبت بـه حالـت بدون شكاف كمتـر مسى شـود. در نتيجـهـ آبشسـتخى در اطـراف آبشكن كمتر مشاهده مىشـود. درحـالتى كـه ارتفـاع شـكاف در
عمـق نسـبى آبشسـتحى در شـرايط نصـب شـكاف در فاصـله

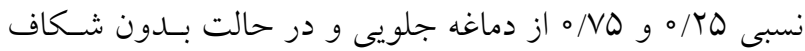
در دو ارتفــاع شـكاف بــا دبسى ثابـت TV ليتـر بــر ثانيـه نشـان مسىدهـد. نتـايج حاصـل از نمودارهـا نشـان مسىدهـــ وجــود شكاف در بدنه آبشـكن در دو ارتفـاع مختلـف، در مقايسـه بـا حالـت بــدون شـكاف (شـاهد)، باعـث كـاهش آبشسـتخى در

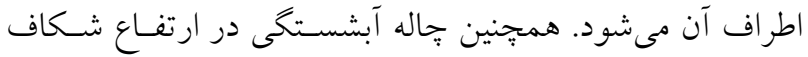



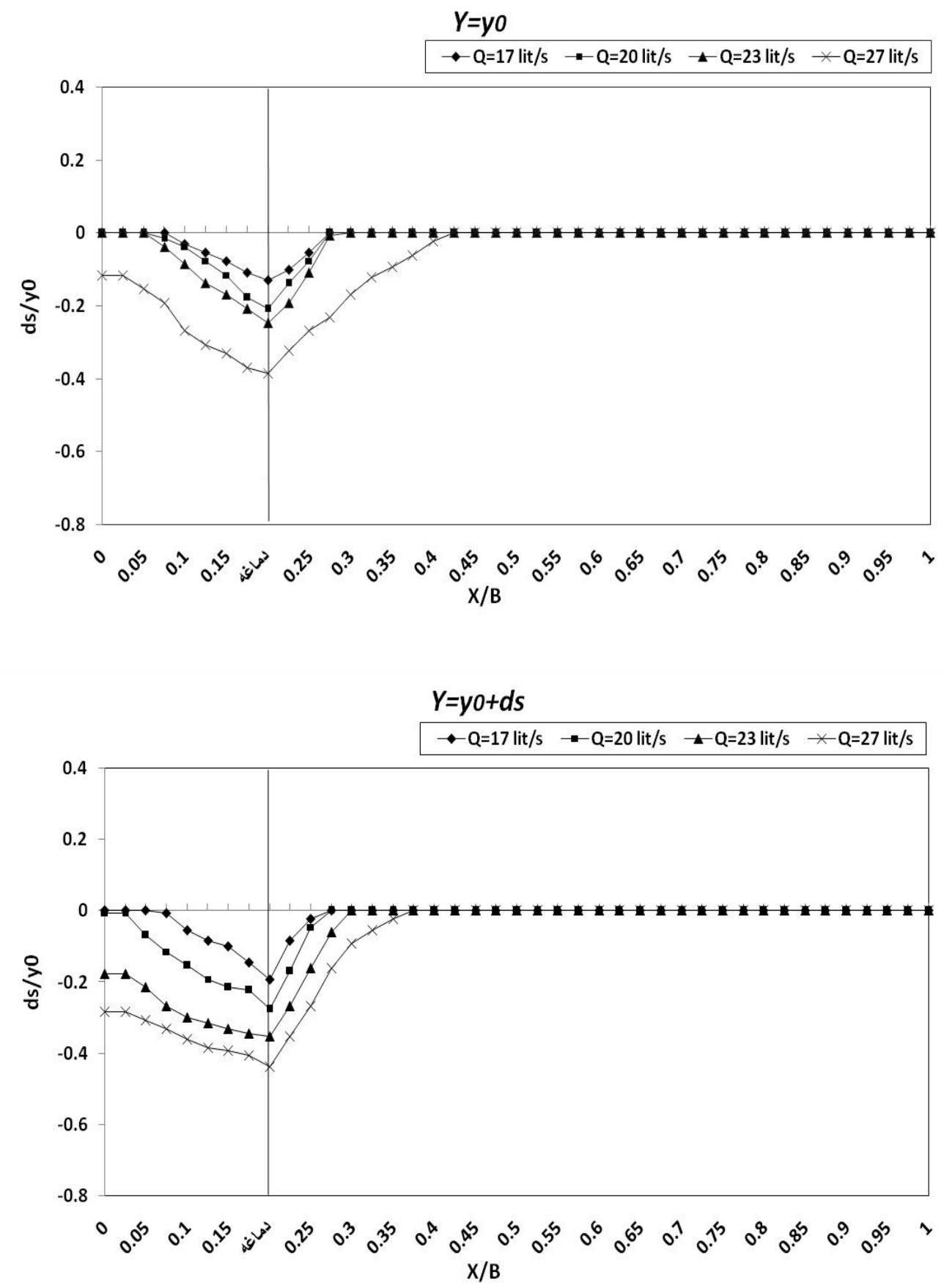

شكل V. بروفيل عرضى جاله آبشستخى در دبىهاى مختلف

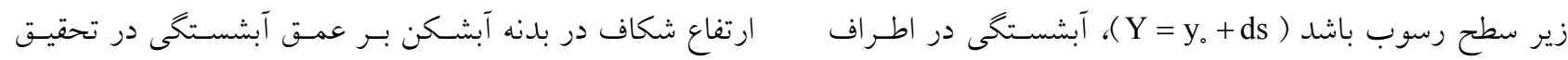

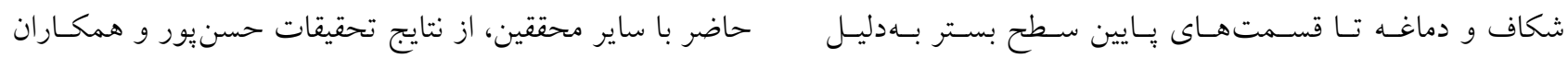

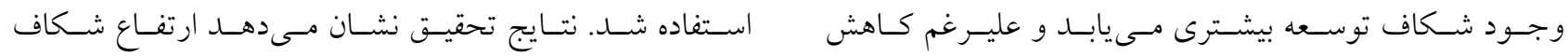

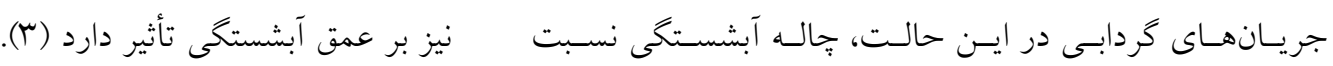
بيشتر مسى شـود. بـهمنظـور مقايسـه تـأثير 

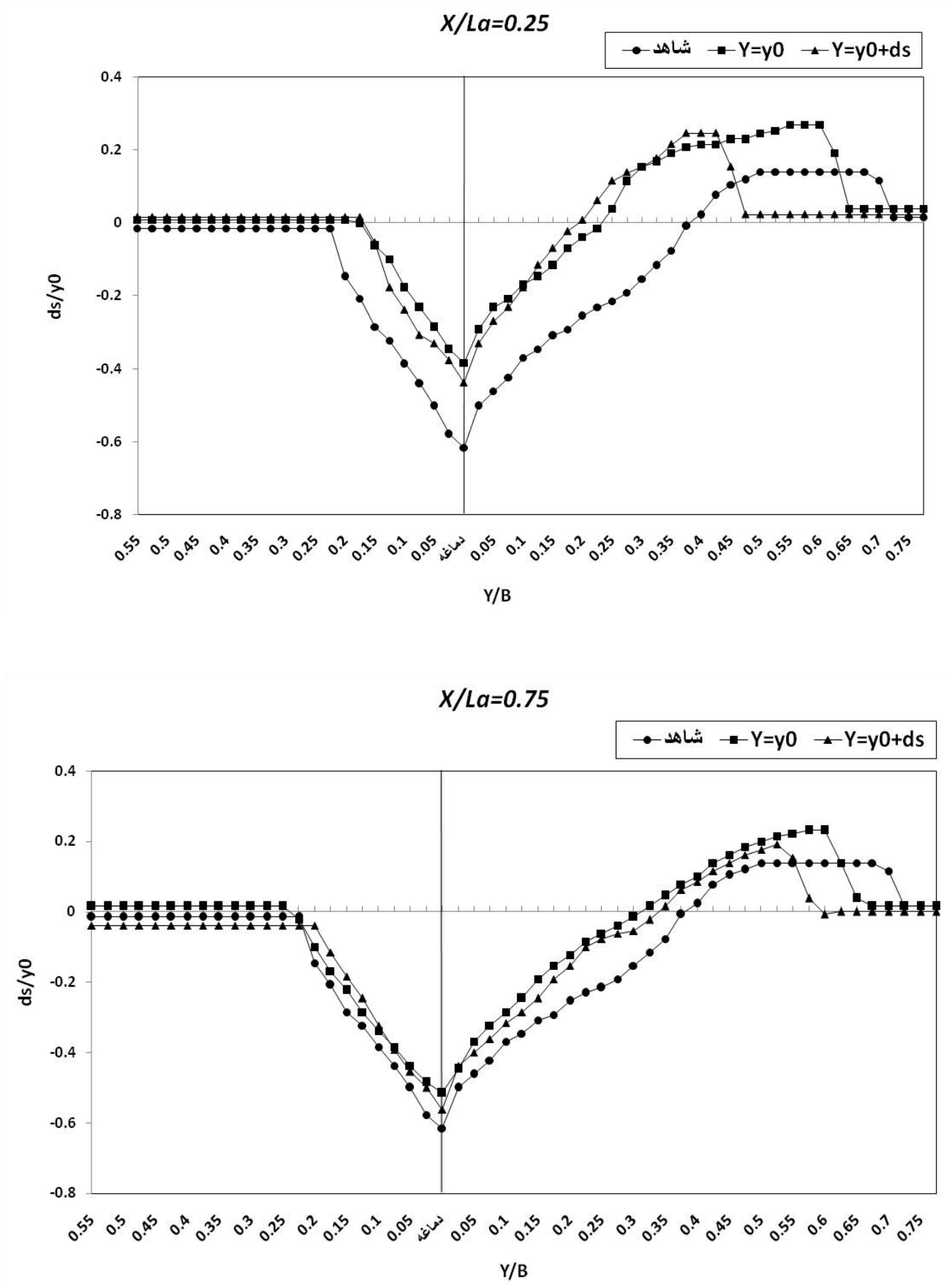

شكل ^^ يُروفيل طولى جاله آبشستخى در دو ارتفاع شكاف مختلف

ثابت انجام شد. متغيرهاى مؤثر در ايسن تحقيـق شـــت جريـان،

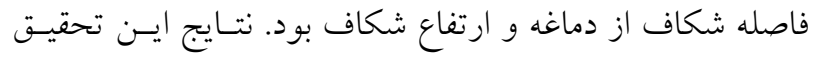

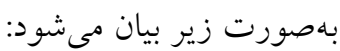

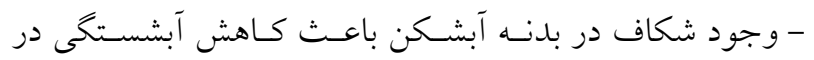
مقايسه با حالت بدون شكاف مى شودد.
نتيجه گيرى

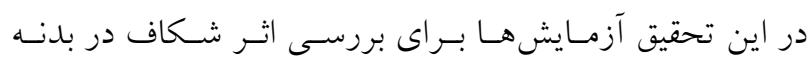

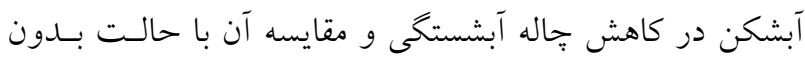
شكاف در قوس •1/ درجه در جهار شـدت جريـان مختلـف، جهار فاصله شكاف از دماغه، دو ارتفاع شكاف و عرض شكاف ترس 

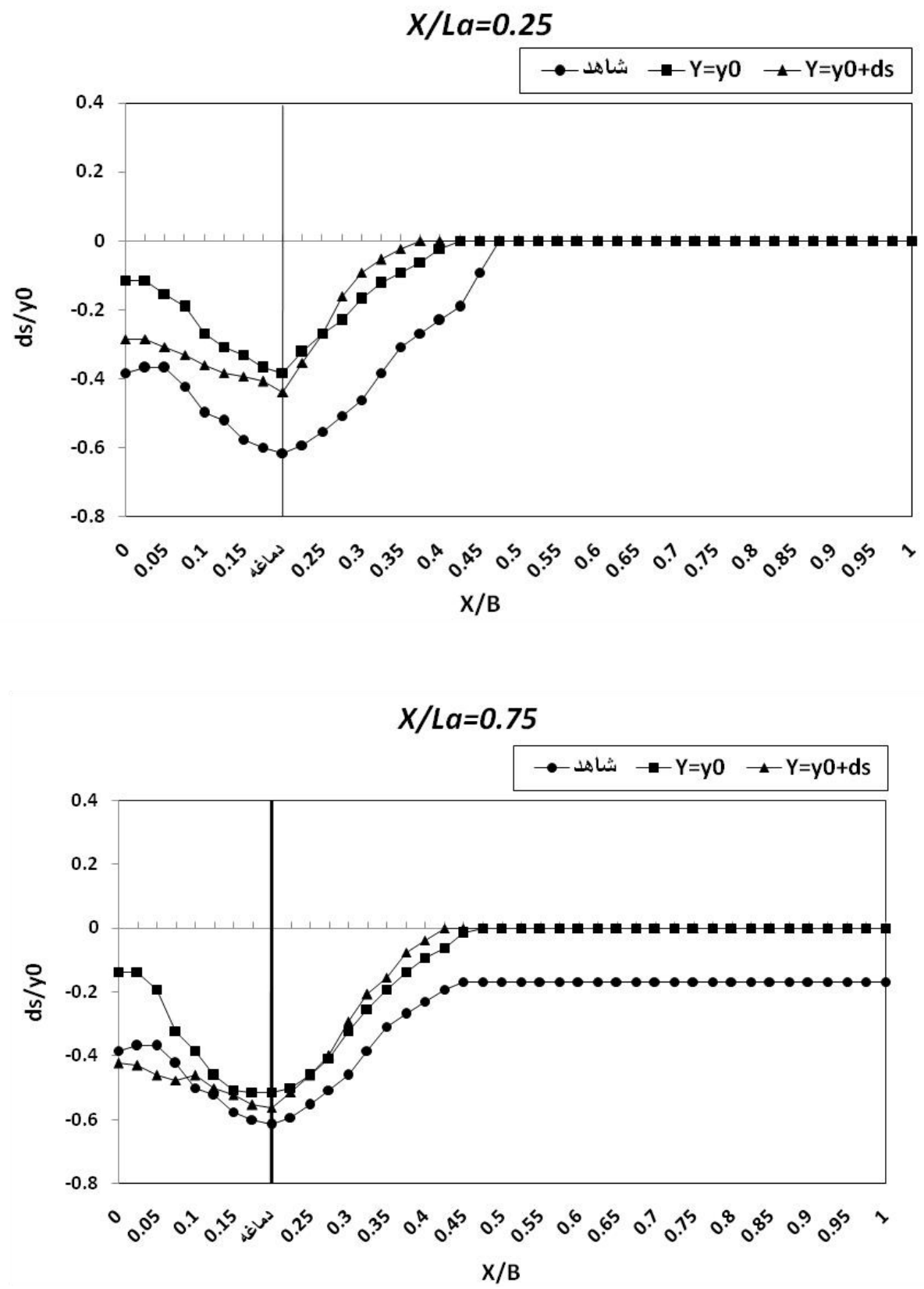

شكل 9.

- وجود شكاف در نزديكى دماغه آبشكن در فاصله نسبى Y تأثير بيشترى در كاهش جّاله آبشستخى دارد و بــا افـزايش ايـن

$$
\text { سياسگگ'ارى }
$$
فاصله از دماغه، ابعاد جّاله آبشستخى افزايش مى يابد. از مساعدت مسئولين محترم دانشخاه آزاد اسلامى واحــد اهـواز

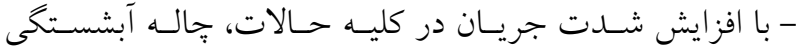
بهمنظور قرار دادن امكانات، تسهيلات و كمكهاى مالى در ايسن

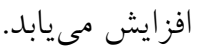
تحقيق تشكر و قدردانى مىشود. - در تمــامى آزمــايشهــا، در حــالتى كــهـ ارتفــاع شـــاف برابر Y=y باشـد، جالـه آبشسـتخى كمتـر از ارتفــاع شـكاف 


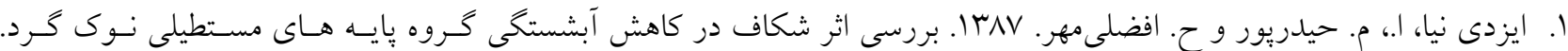
سومين كنفر انس مديريت منابع آب ايران، دانشكده مهندسى عمران، دانشخاه تبريز.

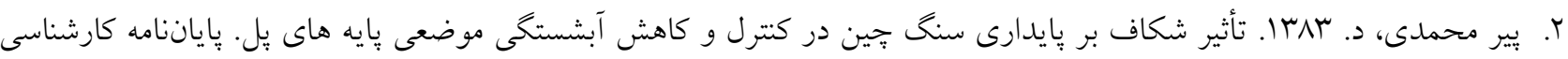
ارشد، گروه آب دانشكده كشاورزى، دانشخاه صنعتى اصفهان.

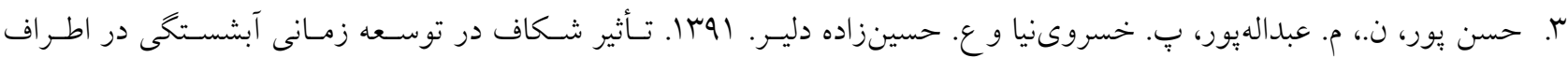
آبشكن. نهمين سمينار بين المللى مهندسى رودخانه، دانشخاه شهيد جّمران اهواز.

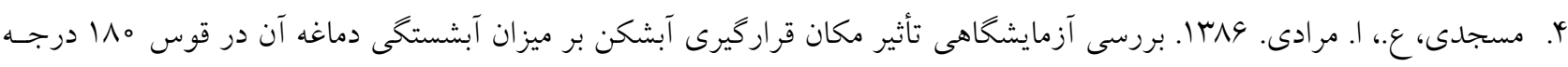
رودخانه ها. ياياننامه كارشناسى ارشد، دانشخاه آزاد اسلامى، واحد علوم و تحقيقات اهواز.

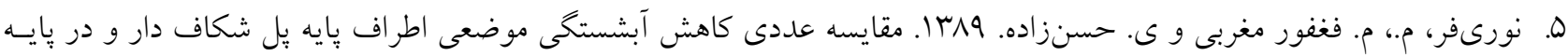
يل مجزا. بنجمين كنگره ملى مهندسى عمران، دانشخاه فردوسى مشهد.

6. Barbhuiy, A. K. and S. Dey. 2004. Local scour at abutments. A Review. Sadhana 29(5): 449-476.

7. Chiew, Y. M. 1992. Scour protection at bridge piers. Journal of Hydraulic Engineering, ASCE 118(9): 1260-1269.

8. Coleman, S. E., C. S. Lauchlan and B. W. Melville. 2003. Clear-water Scour development at Bridge Abutments. Journal of Hydraulic Research, IAHR 41(5): 521-531.

9. Donant, M. 1995. Bio Engineering Techniques for Stream Bank Restoration. A Review of Central European Practices. Watershed Restoration Project Report. No 2. University of British Colombia. Austria.

10. Heidarnejad, M., M. Shafai Bajestan and A. Masjedi. 2010. The effect of slots on scouring around piers in different positions of 180-degrees bends. Journal of World Applied Science 8(7): 862-899.

11. Heidarpour, M., H. Afzalimehr and A. Z. Khodarahmi. 2007. Local scour protection of bridge pier groups using slot. Journal of Agriculture Science Nature Resource 14(3): 174-185.

12. Kumar, V., K. G. Rango Raju and N. Vittal. 1999. Reduction of local scur around bridge piers using slots and collars. Journal of Hydraulic Engineering, ASCE 125(12): 1302-1305.

13. Melville, B. W. and Y. M. Chiew. 1999. Time scale for local scour at bridge piers. Journal of Hydraulic Engineering, ASCE 125(1): 59-65.

14. Moncada, A. T., P. E. J. Aguirre, J. C. Bolivar and E. J. Flores. 2009. Scour protection if circular bridge piers with collar and slots. Journal of Hydraulic Research, IAHR 47(1): 119-126.

15. Raudkivi , A. J. and R. Ettema. 1983. Clear-water scour at cylindrical piers. Journal of Hydraulic Engineering, ASCE 109(3): 339-350.

16. Tafarojnoruz, A., R. Gaudio and F. Calomino. 2012. Evaluation of flow-altering countermeasures against bridge pier scour. Journal of Hydrology Engineering 138(8): 297-305. 


\title{
An linvestigation into the Effect of Slot in Spur Dike on the Development of Scouring Around it in a 180-Degree Bend
}

\author{
B. Jafari and A. Masjedi ${ }^{*}$
}

(Received: May 24-2016 ; Accepted: December 4-2017)

\begin{abstract}
In this study, the performance of slot in the spur dike was evaluated as a way to reduce the scouring around the installed flat spur dike in a 180 degree bend and the development of scouring in the slotted spur dike was compared with that of the spur dike with no slot. To evaluate the effect of the slot on the development of scouring around it, a flat spur dike made of Plax Glass was installed in a position of 70 degrees from a bend (180 degrees) in the flume bed. After determining the maximum of scouring depth at the tip, to reduce the scouring around the spur dike, two slots with the determined height were placed in 4 different positions in the spur dike. Experiments with 4 different discharges and constant flow depth in clear water conditions were conducted. The results of the experiments showed that the created the slot reduced the scouring depth toward the spur dike. In both slots, the minimum of scouring depth was seen in a model with the closest position of the slot toward tip, and its maximum was seen in a model with the farthest position from the slot.
\end{abstract}

Keywords: Spur dike, Slot, Scour depth, 180 degree bend

1. Department of Water Science and engineering, Khuzestan Science and Research Branch, Islamic Azad University (IAU), Ahvaz, Iran.

*: Corresponding Author, Email: drmasjedi.2007@yahoo.com 